\title{
Discursive construction of Syrian refugees in shaping international public opinion: Turkey's public diplomacy efforts
}

Discourse \& Communication

I-20

(C) The Author(s) 2019

Article reuse guidelines: sagepub.com/journals-permissions DOI: 10.1 | $77 /|75048| 3 \mid 9893769$ journals.sagepub.com/home/dcm

\section{Emel Özdora Akşak}

Bilkent University, Turkey

\begin{abstract}
This research focuses on the Turkish government's communications with the international community with regard to Syrian refugees. I use the Discourse Historical Approach to reveal and compare the discursive strategies that the official Turkish news agency has used as part of its public diplomacy efforts in their mass communication efforts regarding Syrian refugees during the last 8 years. The results reveal how a humanitarian issue such as the plight of refugees might be employed to establish a government's political position, affirm its involvement and influence public opinion about a conflict that exceeds national boundaries and has turned into a challenge for international dominance involving world superpowers. The topics highlighted in the Turkish news reports and the argumentations that these reports put forward reveal that the Turkish government is highly critical of the international community, especially Western powers, for not fulfilling their humanitarian responsibilities. This specific criticism from Turkey regarding its outsized role in hosting refugees has become a leverage point to claim a place in the decision table about the future of Syria.
\end{abstract}

\section{Keywords}

Anadolu Agency, critical discourse analysis, Discourse Historical Approach, news agencies, news releases, public diplomacy, Syrian refugees, Turkey

\section{Corresponding author:}

Emel Özdora Akşak, Department of Communication and Design, Faculty of Art, Design and Architecture, Bilkent University, Bilkent, 06800 Ankara, Turkey.

Email: emel.ozdora@bilkent.edu.tr 


\section{Introduction}

Many scholars have investigated refuge and migration issues as a humanitarian crisis impacting many lives and national policies (e.g. Bigo, 2002; Chavez, 2001; Cisneros, 2008; Dimitrova et al., 2018; Fitzgerald et al., 2012; Hercowitz-Amir et al., 2017; KhosraviNik, 2009; Klocker and Dunn, 2003; Van Gorp, 2005). According to the latest official data from United Nations High Commissioner for Refugees (UNHCR, n.d.), Turkey hosts the largest number of refugees in the world, with 3.6 million Syrian nationals residing in the country as of the eighth year of the Syrian conflict. Turkey puts its humanitarian efforts, especially its open-door policy for refugees, at the center of its public diplomacy efforts when communicating with the international community. The purpose of this study is to uncover the Turkish government's official discourse in its communication efforts to the international community about Syrian refugees as part of its public diplomacy efforts.

This study examines how the Turkish government uses public diplomacy through the country's official news outlet, Anadolu Agency. The Anadolu Agency, although it functions as a private enterprise, has been the Turkish Government's official news dissemination system since it was established on 6 April 1920. It has since been instrumental in narrating and explaining the establishment of the Turkish Republic and communicates the '(n)ational struggle in the world, inform(ing) the world public opinion on Turkey's rightful demands' as stated on their website (Anadolu Ajansı History, 2018). The Agency was placed under the control and oversight of the Presidential Communications Directorate by a presidential decree announced on 19 April 2019. Although this oversight was officially transferred only recently, the Anadolu Agency has long been operating in accordance with government policies and acting as the government's official mouthpiece. This study utilizes Wodak's (1996) five-level analytical Discourse Historical Approach (DHA) method to examine the texts in detail and reveal the discursive representations of Syrian refugees in Anadolu Agency news stories (as part of Turkish Government's public diplomacy efforts to promote Turkey's involvement in the Syrian crisis and its humanitarian aid efforts).

Through critical discourse analysis (CDA), I have analyzed 8 years of news releases produced by the Anadolu Agency News Broadcasting System to uncover the major discourses circulated by the government. The results of this analysis reveal how a humanitarian issue such as the plight and despair of refugees might become a critical component of public diplomacy efforts for a government, establishing its position and influencing public opinion about an international conflict as it sustains its position and involvement in this humanitarian crisis. Understanding the language used to cover some issues and how certain issues are salient in media coverage helps create a certain perspective of reality for readers, rendering certain actions and policies natural, meaningful and socially acceptable. This study questions, first, whether the Turkish government has used a strategic discourse to communicate about Syrian refugees, as well as what government actions and policies have been implemented for supporting them. This supports Wodak and Meyer's (2009) argument that discourse 'constitutes situations, objects of knowledge, and the social identities of and relationships between people and groups of people' (p. 16).

CDA investigates language use in detail to reveal the deeper structures and power relations behind the phenomena it investigates. This study provides important lessons 
regarding the discursive strategies that the Turkish government uses to influence public opinion globally. The goal is to expose the context of this media representation and understand 'who is speaking to whom, when, and with what intention' (Van Dijk, 2006: 129). Following the methodology used by KhosraviNik (2009), I have used the five-level analytical method proposed by Wodak's (1996) DHA to reveal the official Turkish news agency's discursive strategies in the media coverage of the Syrian refugees as part of its public diplomacy efforts.

\section{Public diplomacy, public relations and influencing public opinion}

There are many overlapping definitions of public diplomacy. It has been defined as 'a government's process of communicating with foreign publics in an attempt to bring about understanding for its nation's ideas and ideals, its institutions and culture, as well as its national goals and current policies' (Tuch, 1990: 3). It is mainly used to cultivate 'a favorable international/world opinion toward a nation-state' (Wang, 2006: 91), while communicating a state's culture and policies to international audiences globally (Anholt and Hildreth, 2005). Zhang (2006) regards public diplomacy as a process of meaning construction, where states engage in 'exchanging symbols, forming and negotiating meanings, and performing acts based on their respective meanings' (p. 27) to influence public opinion in other countries, mostly through mass media, to turn their foreign policies to their advantage (Sheafer and Gabay, 2009).

Public diplomacy shares many similarities with public relations as it entails communicating with a variety of groups of publics. It is more than merely government relations. It aims to not only 'promote the policies and values of a particular nation but also to engineer consensus and facilitate understanding among overseas publics' (Wang, 2007: 27). A successful public diplomacy strategy entails the successful promotion of countries' issues and images (Sheafer and Gabay, 2009), especially among the international community. Thus, building close connections and establishing understanding are essential to public diplomacy. This reveals the similarities between public diplomacy and public relations. Grunig (1993) supports this idea, arguing that effective public diplomacy consists of applying public relations principles to the management of strategic relationships with international publics. Vanc and Fitzpatrick (2016) make a similar suggestion, claiming that public relations scholarship has much to contribute to understanding how countries establish relationships with international publics. Public diplomacy means that states implement public relations strategies for image building and reputation management purposes, and this involves 'the planned and continuous distribution of interest-bound information by a state aimed (mostly) at improving the country's image abroad' (Kunczik, 1997: 12).

States make use of mediated public diplomacy through national news agencies to frame issues, engage in international agenda setting and influence international public opinion. Historically, the rise of news agencies dates to the second half of the 19th century in Europe. This was the height of increasing nationalism, a point in history where countries tried to legitimate their existence and protect their national interests through the distribution of news abroad (Machin and Van Leeuwen, 2007). In the past, only a few privileged countries had the luxury of shaping international public opinion through globally networked news 
agencies, which collectively held a strong influence over mass media. However, many believe that in the 21 st century, non-Western nations have gained the power to challenge the hegemony of old world powers in international as well as national affairs (Asante, 2014; Tehranian, 2014; Xu, 2014). These countries have introduced or are now introducing their own set of communication norms and traditions, which may reject or contradict the old world powers' domination of the international political order (Mowlana, 2016).

\section{Studying refugees and their representation through discourse analysis}

An important method to reveal these discursive framing strategies utilized in media representations (as part of public diplomacy efforts of governments) is CDA, which unmasks and deconstructs media texts. Guilfoyle and Hancock (2009) recommend analyzing texts for content, construction and function to reveal how discourse is structured, and thus understand 'what is gained by constructing the issue, event, and/or subject in this way?' (p. 27). Hidden in this question is 'power', as in who controls coverage and thus controls how issues are framed as well as the discourses that mass media puts forward. As Young (1981) has argued, discourse is constructed as a result of power relations; it also ensures the reproduction or questioning of the same power structures through the use of selection, exclusion and domination strategies. Discourse constructs social realities: it is 'through individuals' minds that it influences people and then shapes their actions' (Lihua, 2012: 250).

Mass media, with its representations or (mis)representations, can serve as a prominent and socially relevant example of the (re)production of ideological discursive practices. Discourse not only serves to reflect social realities but it actually constructs them for the consumers of texts (Phillips and Hardy, 2002). Van Dijk (2006) pinpoints newspapers as powerful 'business' institutions that not only reproduce but co-produce ideological representations and reflect the ideological positions of their interests as 'faithful mouthpieces of the owners' (p. 138). Mass media may function as the mouthpiece of governments and other dominant power structures to protect their 'interests'. Studying media texts allows researchers to unmask these ideological representations and power structures, which is critical because of how effective media discourses can be in shaping public perceptions (Fairclough, 1989, 1995) and understanding the underlying ideologies as well as the political power games in play. Discursive strategies used to represent unequal power relations influence the public's perception of and reaction to 'social classes, women and men, and ethnic/cultural majorities and minorities' (Fairclough and Wodak, 1997: 258). CDA assumes that inequalities, exclusions, subordinations and power relations tend to be established, transferred and legitimized through language, and uncovering these meanings involves an in-depth engagement with texts.

\section{Unmasking discourse through the DHA}

Context and historical background are critical to discourse analysis. CDA analysis has roots in the study of politics from a historical perspective (Wodak and Meyer, 2009) and aims to reveal societal 'inequalities, injustices and oppression' (Van Leeuwen, 2008: 278). An important strand of CDA that specifically focuses on historical context is the 
Table I. DHA dimensions by Reisigl and Wodak (2009: I3).

\begin{tabular}{ll}
\hline Naming/Labeling & How are phenomena named and referred to \\
linguistically? & How are references made to refugees? \\
& Which names, linguistic devices and labels are \\
& commonly used in media texts? \\
& What characteristics, qualities and features are \\
& attributed to the phenomena? \\
& Which characteristics, qualities and features \\
Predication/Attribution & (traits) of refugees are emphasized in media \\
& texts? \\
Perspectivation & From what perspectives are these attributions \\
& expressed? \\
& Which position or stance is adopted in the \\
& media texts toward the refugees; what are the \\
& means of reporting, description, narration or \\
& quotation of events and utterances? \\
& Are utterances and arguments intensified or \\
Intensification/Mitigation & mitigated? \\
What valence or tone is mostly used in the \\
media texts in relation to refugees? \\
What arguments are employed in the discourse \\
to justify political inclusion/exclusion? \\
Which major issues/topics are refugees \\
connected with in the media texts?
\end{tabular}

DHA: Discourse Historical Approach.

DHA. Initially developed by Wodak (1996), DHA integrates analysis of historical context with the interpretation of textual data (Wodak and Meyer, 2009). DHA has been used in many studies of discourse, and it incorporates three dimensions to the in-depth textual analysis: 'the content of the data, the discursive strategies employed, and the linguistic realization of these contents and strategies' (Van Leeuwen and Wodak, 1999: 91). The historical dimension of discursive strategies is integrated into the analysis by embedding the historical discursive events as well as how these discourses evolve or change over time (Van Leeuwen and Wodak, 1999). The five dimensions of DHA include the discursive strategies used in the text for naming/labeling, predication/attribution, perspectivation, intensification/mitigation, and argumentation/topoi (Reisigl and Wodak, 2009). How each of the dimensions is studied is explained in Table 1, by presenting the questions used to analyze each dimension.

Based on the literature presented above, the following research questions are proposed:

$R Q 1$. What linguistic terms are used to define and refer to refugees in the news which labeling/naming strategies are used as part of the discourse?

$R Q 2$. Which characteristics and qualities are attributed to the refugees - which predication/attribution strategies are integrated in the discourse? 


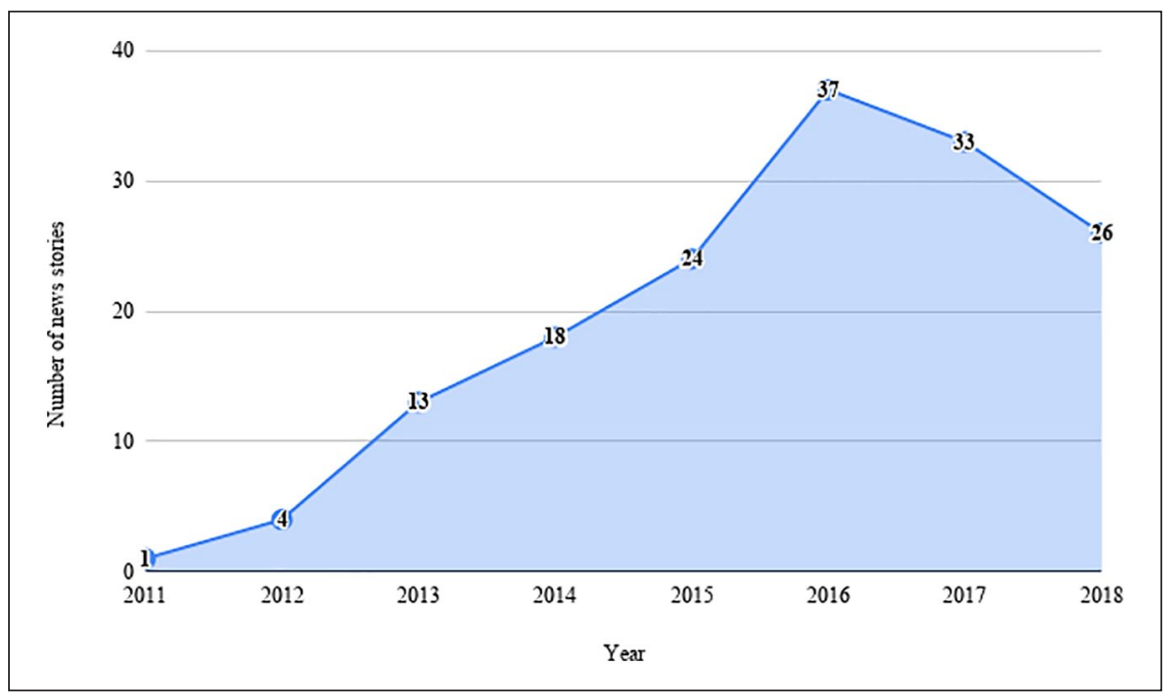

Figure I. Annual distribution of Syrian refugee news stories from Anadolu Agency, 20II-20I8.

$R Q 3$. What is the position or stance in the news toward refugees - which perspectivation strategies have been used as part of the discourse?

$R Q 4$. What is the valence/tone reflected in the news, which aspects are intensified, and in contrast, which aspects are mitigated?

$R Q 5$. Which issues/topics are refugees connected with in the news?

\section{Methodology}

The study covers the Anadolu Agency's news coverage of the Syrian refugee crisis between the years 2011 and 2018. A Lexis-Nexis news database search with the keywords 'Turkey Syrian refugees' identified a total of 156 news stories from 9 June 2011, marking the beginning of the arrival of Syrian refugees to Turkey, through 31 December 2018 when the data collection was completed. The search might have brought more news stories with the key term 'Syria'; however, as my intention was to find stories focusing specifically on Syrian refugees and Turkey, this is the rationale behind the more limiting keyword search. Figure 1 reveals the distribution of the Anadolu Agency news stories about Syrian refugees over 8 years; only one article published on the issue appears in 2011, while peak interest comes in 2016 and 2017 and then declines in 2018. The upward trend reveals the increasing popularity of the topic for Anadolu Agency and, therefore, increased focus on the issue for the Turkish government's public diplomacy efforts. The peak in 2016 might be related to the EU-Turkey deal, discussed in detail below, and the decline in stories in 2017 and 2018 might be attributed to news fatigue on topics related to refugees. 
Once the news stories were identified, the dataset was a 61,500-word long text document, with the average story consisting of 395 words. The shortest was 104 words, and the longest was 1115 words. The news stories were copied to a separate word processing document and analyzed qualitatively through a detailed textual analysis. This allowed me to unearth the recurring discursive strategies used in the coverage of refugees across the news through the use of DHA dimensions. The texts were read and reread carefully to reveal keywords, terms and phrases. Following the approach used by Gabrielatos and Baker (2008), I examined the linguistic indicators and lexical items such as adjectives, attributes, metaphors and verbs related to the research questions to identify how these discursive strategies were used in each text and developed over time. In my analysis, I noted recurring words, phrases and arguments to identify major patterns in the text. The multiple, detailed readings of the textual content, a process unique to the text-driven and text-focused nature of discourse analysis tradition, allowed the themes and textual content of the news stories to guide the coding process.

I used DHA dimensions as a framework to categorize the thematic content of news articles. The texts were coded through multiple readings and detailed analysis of keywords, terms and phrases related to the research questions and DHA dimensions. The categories and codes that emerged from the articles were converted into a code sheet, and the data were coded in a separate spreadsheet document according to DHA categories. The first DHA dimension, labeling/naming strategies, made it easy to identify news stories that referred to the nationality of the refugees as either 'Syrians' or 'Syrian refugees', but some also referred to them based on their age (babies, children, youth), gender (women, girls), their relationship to Turkish citizens (guests, neighbor) or legal status (migrants, those with work permits, etc.). The second DHA dimension, predication/attribution strategies, was grouped according to characteristics attributed to Syrian refugees; I coded these using two categories: victimization, referring to Syrians refugees as victims of violence and atrocities especially with mention of personal stories and human tragedies; collectivization, when they were merely mentioned through large numbers. Third, I continued the detailed analysis to identify perspectivation strategies by examining in detail the position or stance in the news article; here, articles were coded for external praise coming to Turkey from others; self-praise when Turkish officials/authorities were praising Turkey's efforts in supporting refugees. In addition to the two forms of praise, a third perspectivation strategy is criticism of others and call to action to urge states and actors outside Turkey to contribute more support.

Then I examined the valence/tone of the news story, looking specifically for aspects that were intensified (heavily emphasized) or mitigated (repeatedly minimized). Finally, I coded for three types of argumentations/topoi through which refugees could be connected with, first, the topos of being a good host by mentioning Turkey's open-door policy, the shelter and services the state has provided to refugees, projects and programs implemented to support them; second, the topos of aid, which includes any mention of funds provided to refugees, the EU deal and/or collaboration and partnerships between organizations; and finally, the topos of future that includes either a return home or integration of refugees as potential outcomes for the future.

The coding categories were not mutually exclusive, and the same news story could be coded in multiple ways, even under the same DHA category. For example, one news 
Table 2. Frequencies and percentages of DHA dimensions and thematic content.

\begin{tabular}{llcr}
\hline DHA categories & Thematic contents & Frequency $(\mathrm{n}=156)$ & $\%$ \\
\hline Referral/naming & Age & 58 & 37 \\
& Gender & 18 & 1 I \\
& Relationship (i.e. brothers and sisters, neighbors, & 19 & 12 \\
& guests, doctors, nurses, teachers) & & 15 \\
& Legal status (i.e. work permits, displaced people, & 24 & \\
& temporary protection, registered, asylum seekers, & & 29 \\
& migrants) & & 69 \\
Predication & Victimization & 45 & 37 \\
& Collectivization & 107 & 17 \\
Perspectivation & External praise & 58 & 31 \\
& Self-praise & 26 & 16 \\
& Criticism and call to action & 49 & 10 \\
Valence-Tone & Intensification & 25 & 46 \\
& Mitigation & 16 & 38 \\
Argumentation & Good host & 72 & 15 \\
& Aid & 59 & 24 \\
\hline
\end{tabular}

DHA: Discourse Historical Approach.

article could include both collectivization by referring to refugees in large numbers and also be coded positive for victimization by providing human interest stories based on refugees' personal tragedies. The same news article could also use intensification strategy to highlight Turkey's efforts in supporting refugees while at the same time using a mitigation discursive strategy to talk about the relatively small scale of European aid received or number of refugees hosted in other countries. The same news article could mention topos of being a good host and topos of aid in providing details about services provided to refugee women and girls in Turkey, while also talking about the funds spent for refugees and joint EU and UN projects. Findings from the analysis are presented in detail below.

\section{Results and discussion}

The coding of the news stories revealed that the most common DHA category was collectivization, with almost $70 \%$ of the articles referring to refugees through large numbers as a predication strategy. Topos of being a good host was evident in almost half of the news articles (46\%) and topos of aid was seen in 38\% of the news articles. A detailed list of all frequencies and percentages are presented in Table 2, and the following paragraphs will go in-depth into the analysis while providing examples of the discursive strategies used.

The first research question, which focuses on the referral/naming component of the DHA, defines who the social actors are and how they are defined. The Anadolu Agency news stories refer to Syrian refugees by their nationality, age, gender, relationships and legal status. All 156 articles use nationality when naming them, such as 'Syrian 
citizens', 'Syrian people' and 'Syrians'. Reference to the young Syrian refugees is emphasized in $37 \%$ of the news stories, where they are referred to as 'Syrian babies', 'Syrian children' or 'Syrian refugee children', 'school-aged Syrian refugees', or 'Syrian youth'. Another point the news articles highlight is gender, as the number of women and girls is specified in $11 \%$ of the articles. Syrian refugees are also referred to as 'our guests', 'neighbors' or even 'our brothers and sisters' in $12 \%$ of the news stories, while $15 \%$ highlight their legal status with terms as 'asylum seekers', 'migrants' or 'those with work permits'.

The second research question on predication/attribution examines the characteristics, features, qualities attributed to social actors, phenomena, events and processes. Descriptions of Syrian refugees in the news stories are narrated through victimization and/or collectivization or by mentioning the crisis and conflict. Sympathetic macro structures of support and dramatization are used to highlight the victimization of refugees in almost $30 \%$ of the news stories, where the tragic aspects of refugees' plight are amplified. Some examples of this are, 'those fleeing tyranny and oppression' (21 September 2016), 'Turkey has been the first port of call for millions of desperate men, women and children forced to abandon their homes, jobs, schools and families' (1 October 2015), 'Syrian refugees who fled the country to save their lives from the Syrian army's brutality' (29 August 2013), 'The number of Syrian refugees taking shelter in the refugee camps and several provinces in Turkey' (22 May 2013) and 'Syrians who fled the relentless violence that has engulfed their country for 18 months' (13 September 2012). These descriptions of victimhood clearly underline that refugees are in despairing need of humanitarian care and protection.

To predicate the condition of Syrian refugees in Turkey, another attribution strategy is collectivization, which uses numbers to accentuate the scale of the refugee issue. Almost $70 \%$ of the news stories use collectivization. Water metaphors - the terms 'influx' and 'wave' - are frequently used in this context: 'large influx of Syrian refugees fleeing the civil war in their country' (11 June 2015), 'a massive influx of refugees' (24 October 2014), 'refugee migration waves' (9 February 2016), 'a new wave of migrants' (12 February 2016), 'flow of refugees' (9 September 2015). The reports provide the number of refugees registered in the country, and breaks these numbers down according to cities. They also comment on the number of refugees who are staying in camps, the number of children and women and the number of people who benefit from certain services. Some examples are, 'a five-fold increase in the number of refugees since last winter' (16 December 2013), 'Turkey hosts the highest number of refugees in the world' (19 September 2015) and 'thousands of refugees continued to flock' (19 September 2015). According to the United Nations Refugee Agency (UNHCR), 'Turkey hosts up to 3.6 million Syrian refugees as well as hundreds of thousands from Afghanistan, Somalia and Iraq, a figure that represents 4 percent of the Turkish population' (10 May 2018). In addition, news reports refer to Syrian refugees in Turkey according to different categories, such as 'students', or group them according to their gender or age: 'There are 3.42 million registered Syrian refugees in Turkey. While 1.85 million of them are male, 1.57 million are female. Some 2.46 million of the refugees are under 29 years old, and there are over 515,000 children age 4 and under' (17 January 2018). They are referred to in groups, according to where they are located in Turkey: 'There are some 132,000 Syrians present in Kilis while the city's non-refugee population is about 131,000 ' (14 March 2018), 'Nearly 538,000 Syrians live in Istanbul, a 
metropolis with a population of almost 15 million, which make up 3.63 percent of Istanbul's total population. Turkey's southeastern province of Sanliurfa hosts nearly 463,000 Syrians, while over 457,000 Syrians live in the Hatay province on the Turkish-Syrian border. Over 228,000 Syrians are living in 21 camps in 10 provinces of Turkey' (17 January 2018).

The third research question on perspectivation makes reference to the different perspectives from which these attributions/arguments are expressed. Anadolu Agency consistently utilizes two major perspectives related to praise: external praise for Turkey in its efforts hosting refugees, present in $37 \%$ of the news articles and self-praise by Turkish authorities, present in $17 \%$. One example of external praise coming from Syrian refugees themselves is, "Syrian refugees in a Turkish refugee camp expressed deep gratitude towards Turkey, saying it had effectively saved their lives, treating them like brothers and providing for them' (20 February 2017). Duaa Alhussain, a Syrian woman refugee aged 21 and residing in Turkey, praised the Turkish hospitality for Syrian refugees, saying, 'No other country did what Turkey did for Syrian refugees. This beautiful country has opened without any restriction its doors to Syrians like me, I want to thank people in Turkey and particularly the country's leader Recep Tayyip Erdogan' (15 December 2015). Another Syrian refugee, Sharif Sheik, who resides in the Elbeyli refugee camp, stated that the Turkish government and Kilis residents had treated Syrian refugees 'like a brother', sharing 'their bread and even homes without expecting anything in return' (25 February 2016).

Other non-Turkish actors, mostly European officials, have praised Turkey's hospitality and support for Syrian refugees. Some important figures from international organizations include the president of the European Parliament Schulz, who praised Turkey for hosting Syrian refugees and expressed hope that Turkey will continue to do 'a great job' (14 April 2015). Atassi of UNHCR stated that 'Turkey's hosting of close to two million Syrian refuges has created a model for the management of asylum seekers and migrants, the Turkish model' (11 June 2015). Guterres, the UNHCR High Commissioner at the time and UNHCR Special Envoy Jolie have also praised 'Turkey's efforts to assist the Syrians who are fleeing the violence in their country', during their multiple visits to refugee camps (14 September 2012). European Commissioner for Migration, Home Affairs, and Citizenship Avramopoulos praised Turkish hospitality by stating, 'I would like, on behalf of the EU, to praise and commend Turkey once again for its tremendous hospitality and enormous humanity that it has shown towards these desperate people' (28 November 2017). German State Minister Bohmer applauded Turkey's efforts to provide education to Syrian refugee children. 'Educating children is important and as far as we see, Turkey is providing key education' (29 April 2015).

The other form of praise is self-praise coming from Turkish officials, congratulating Turkey's efforts in sheltering and supporting Syrian refugees. Van Dijk (2003) referred to this praise for one's own country as national self-glorification. The Anadolu Agency's news stories are full of examples of national self-glorification or self-praise in taglines such as 'Ankara has spent $\$ 25$ billion helping and sheltering refugees since the beginning of the Syrian civil war. The country, with its state-based institutions and many non-governmental humanitarian aid organizations, is making every effort to meet the needs of Syrian refugees, including shelter, food, clothing, health, and education, as well as social activities to make their lives easier' (1 December 2017) or 'Turkey hosts the largest 
number of refugees in the world and spends more per capita GDP on the wellbeing of refugees than any other nation in the world' (10 May 2018). In addition, some news stories highlight the self-praise of Turkish government officials. Deputy Chairman of the Directorate General of Migration Management Hacibektasoglu said, 'Be it Syrians or Iraqis, Turkey has opened its doors to these people. We cannot take any other position than that. We are proud of the Turkish people' (11 June 2015). Turkish Deputy Parliament Speaker Aydin said, 'We did not only open our doors to our Syrian brothers but also our hearts, we shared our bread with them' (20 November 2017).

The last component of perspectivation is criticism and call to action. This consists of Turkish authorities' criticisms of the international community for their lack of support as well as a request for more support for refugees. The Anadolu Agency often uses this tagline: 'The EU promised to initially allocate 3 billion Euros for projects supporting Syrian refugees, but Turkey has so far received only 800 million Euros' (14 March 2018). This critical discourse became particularly evident after the March 2016 EU-Turkey refugee deal. Since that point, news stories often mention the EU deal between Turkey and EU member states, and criticize the lack of or delay in the transfer of promised funds. In his UN General Assembly speech, President Erdogan stated that the EU has let Turkey down by not holding to its commitments under the refugee deal: 'the promises made by the EU to Turkey have unfortunately not been kept', and he called on world leaders to share the burden (21 September 2016). Other Turkish officials such as Vice President Oktay, Minister of Education Avci, Family and Social Policy Minister Sayan Kaya and other MPs, have criticized the EU for not delivering funds or keeping its promises under the 2016 deal. But in these news stories, it is not only Turkish officials who express criticism or call for greater involvement from other states. EU Budget Commissioner Oettinger specifically called EU states to honor the EU-Turkey refugee deal and 'allocate more than 2 billion Euros from their national budgets by the end of 2018' (25 August 2017). Burgeon from UN Food and Agriculture Organization's Emergency and Rehabilitation Division requested more funds from more donors in order to 'do more' (9 April 2018) and German Chancellor Merkel reiterated that the EU 'must fulfill its commitments under the agreement' (29 November 2016). Yet the call was also for more awareness and acceptance. The Jordanian ambassador to Turkey, Al-Adaileh, stated that the Syrian crisis should be a priority of Muslim countries, calling for 'Muslim and Arab countries' to accept Syrian refugees (7 March 2017).

The fourth research question focused on the valence or tone reflected in the news stories, specifically analyzing which aspects are intensified and which are mitigated. In all, $16 \%$ of news stories use intensification to amplify the high number of refugees, high amount of funds and significance of Turkey's support. A common tagline reads 'Turkey, as the largest refugee hosting country in the world, hosts more than 3.5 million Syrian refugees' (28 March 2018), a figure which matches the official number presented by UNHCR. The reported numbers may change, but the emphasis on highest number is evident throughout the period of the study. Some news stories provide a detailed breakdown of the distribution of refugees across Turkey or highlight the funds spent to host them: 'Turkey is hosting around 260,000 refugees in camps in its eastern/southeastern provinces of Hatay, Gaziantep, Sanliurfa, Kilis, Mardin, Kahramanmaras, Osmaniye, Adiyaman, Adana, and Malatya. Turkey now hosts some 3 million Syrian refugees, more 
than any other country in the world. The country has spent around $\$ 25$ billion helping and sheltering refugees since the beginning of the Syrian civil war' (20 February 2017). Quotes by national and international figures further highlight Turkey's efforts to host high numbers of refugees. Turkish Development Minister Yilmaz said, 'Turkey has been the hardest-hit by the Syrian crisis. As of March 2015, more than seven million Syrians will benefit from the Turkish welfare system' (31 March 2015). It is hard to understand where this number comes from; it can be seen as an example of intensification. UNHCR External Relations Officer Saltmarsh is quoted saying, 'I often ask the audience ... Which country is the largest host of refugees in the world? And the answer is varied, but very rarely is it Turkey . . . So that's a fact that is surprisingly little known, I think, in the world. And of course, no country has done more to shelter the homeless and shocked population of Syria than Turkey' (10 May 2018).

On the other hand, $10 \%$ of the news stories use mitigation to criticize the lack or insufficiency of international contributions. They also reference the low numbers of refugees hosted globally. AFAD Director General Oktay has stated that while Turkey has spent $\$ 5.5$ billion to support Syrians in Turkey, 'The international community has spent $\$ 306$ million for the Syrians, unfortunately' (14 April 2015) and 'financial aid from the international community is merely at \$264 million' (7 January 2015). Another commonly repeated theme is the discrepancy between the funds Turkey has received from the EU and the figures they had been promised: 'The EU promised to initially allocate 3 billion Euros for projects supporting Syrian refugees, but Turkey has so far received only 800 million Euros' (14 March 2018). Another mitigation strategy is to underline the small number of relocated individuals. According to an EU Commission report, 'the total number of relocations stands at 31,500, far below its (EU) goal of relocating 160,000 refugees' under the EU-Turkey deal (16 November 2017).

The fifth research question on argumentation/topoi refers to discourse employed when justifying political inclusion or involvement or the major issues refugees are connected with. In this context, three main areas of discursive argumentation strategies have been identified: the topos of being a good host (46\%), topos of aid (38\%) and topos of future (10\%). Turkey's open-door policy was coded as part of topos of being a good host. It openly welcomes refugees and continues to be implemented 'despite currently hosting more Syrians than any other country in the world' (20 May 2016). According to the Deputy Prime Minister Akdogan, Turkey is 'opening our gates and embracing all those who flee death and fear of their lives' (21 February 2016).

Providing services to address the physical, social and psychological needs of refugees highlights the second component of the discursive strategy topos of being a good host. This includes access to key services such as education and vocational training, healthcare, legal procedures and rights, as well as shelter in camps and elsewhere. Educational services include teaching Turkish, English and Arabic language courses as well as providing vocational training for adults and children (4 July 2017) as in the case of a 105 million Euro project to ensure 'access to vocational training, income and employment generation', (20 June 2017). There are also campaigns to 'raise awareness against child marriage' (20 November 2017) or enable refugees 'to grow their own food and get skills to be able to work in agricultural sector in Turkey' (9 April 2018). The educational and training services target adults and children, as 'half a million Syrian children have been 
integrated into the education system in the 2016-2017 academic year' (20 November 2017). They are offered free educational services (13 February 2017) in education facilities constructed mainly for Syrian refugees in Turkey's southern provinces (27 September 2017). In addition to education and training services, around two million people are able to access healthcare (28 November 2017), with over 178 migrant health centers in Turkey established largely to provide healthcare services to Syrians (30 September 2017). These employ up to 1500 health personnel, including Syrian doctors and nurses. These rights and legislative services are other topics that the news stories underline in reference to the high number of people who hold residence permits (4 October 2017) and work permits (23 May 2016) and have 'temporary protection status, giving them the right to work' (1 March 2017). The news stories also note how the most vulnerable refugees receive 'monthly electronic cash transfers to cover their everyday needs' (28 November 2017).

The second discursive argumentation strategy used is topos of aid, which highlights funds allocated to Syrian refugees, partnerships between various institutions to support refugees and the $2016 \mathrm{EU}$ deal. News stories mention the impressive pledges to support refugees, often tallying astronomical sums of money. Some examples of financial aid are, '(Turkey has) spent more than $\$ 32$ billion from its own national resources for helping and sheltering refugees since the beginning of the Syrian civil war' (28 November 2018) and '(U.S. assistance for Syrian refugees exceeds) $\$ 3$ billion since the crisis began in March 2011, including more than \$222 million for international organizations working with the Turkish government' (23 November 2014).

Another important argument related to the topos of aid is the partnerships that highlight collaborations to support Syrian refugees living in Turkey. These partnerships may involve various non-governmental organizations (NGOs), the EU, the World Bank and UN Organizations. Some of these partnerships are organized around joint projects such as a 150 million Euro Education Infrastructure for Resilience Project. This is funded by the EU and administered by the World Bank to aid Turkey in providing education for Syrians under temporary protection status. Other partnership examples include the Turkish Red Crescent and the International Federation of Red Cross and Red Crescent Societies (IFRC) coordinating a program to build community centers for refugees across Turkey (4 July 2017) and the Turkish Red Crescent and UNHCR providing hygiene and sanitary products to refugees (28 September 2016).

The last argumentation strategy under the topos of aid is the March $2016 \mathrm{EU}$ deal. The EU and Turkish Government signed the deal to stem the irregular migration flow through the Aegean Sea by implementing stricter measures against human traffickers and improving conditions for nearly three million Syrian refugees in Turkey. In exchange, the deal suggests the acceleration of Turkey's EU membership and potentially promises visa-free travel for Turkish nationals within the Schengen area if Ankara meets all 72 EU requirements. The deal promises EU support through an EU Regional Trust Fund to implement projects to support refugees in vocational training, language education, improved access to healthcare, and healthcare skills building, as well as capacity building of local authorities (20 June 2017).

The final discursive argumentation strategy, used in $10 \%$ of the news stories, is the topos of future, which centers either the return home of refugees once stability is reestablished in Syria, or their integration into Turkish society. The return home rhetoric is 
based on the argument that Syrian refugees will eventually return back to Syria once peace and stability are restored. International actors use this argumentation strategy. UNHCR Turkey Representative Batchelor stated that '(w)e need to empower the Syrian people and bridge them to the time when they can return and rebuild their country. This is an investment in the future for all of us' (22 September 2014), and ILO Director General Ryder said that refugees themselves also expect to return home (23 May 2016). Anadolu Agency also gives voice to Syrian refugees living in Turkey. Syrian Dr. El Hatip, working in the Artuklu healthcare center, was hopeful about the future and the prospect of helping people in his or her homeland: 'God willing, we hope the war will soon end' (4 July 2018). Twenty-five-year-old al-Ahmad was also thankful for 'the atmosphere and opportunities provided in the container city but is praying for the conflict in to end so she can return to her home country' (10 February 2014). Taha, another refugee residing in the Akcakale town of Sanliurfa, stated that once the soldiers fighting under coercion leave the Syrian army, it will weaken and they will be able to return to their country (29 August 2013). As these examples show, the hope to go back home never disappears. But this rhetoric is also popular among Turkish authorities. Justice Minister Gul referred to Syrian refugees as 'guests' and argued that 'as Syria becomes more safe with [Turkey's military] operations Euphrates Shield and Olive Branch, our guests want to go back to their homeland' (11 June 2018). Deputy Director General of Migration Management Ayaz underlined the 'willingness of Syrians to return to their country if security is established within Syria' (21 December 2017).

Implicitly rejecting the return home discourse, the integration argument of the topos of future focuses on the successful integration of Syrian refugees in Turkey. UNFPA Turkey representative Kulessa stated, 'the real challenge will begin when we come to integration', where Turkey will face economic, social and cultural challenges in integrating such a high number of refugees (4 May 2016). Anadolu Agency news stories include references to various projects to ensure the integration of refugees. For example, a 650 million Euro EU project was implemented to ensure that Syrian children integrate successfully into the Turkish education system by mastering the Turkish language and continuing their higher education (6 October 2017). UNHCR Deputy Representative Artini stated that the Turkish projects mainly strive to help refugees 'to live in dignity, and develop policies for their integration into the Turkish society' (14 September 2017). Turkish officials also emphasize the national policies that support the integration of Syrian nationals (14 September 2017). Ankara-based think tank SETA's education expert Emin stated that 'Turkey should not approach refugees as guests but as individuals who can be permanent citizens in the near future', where their employment 'would integrate them into Turkey in peaceful and well-ordered conditions as well as preventing human trafficking to EU countries' (9 May 2016). In fact, Anadolu Agency Deputy Director Mutanoglu stressed the reason why the agency includes stories about the social integration of refugees: 'Our colleagues often write interesting real life stories of Syrians. For example, there are Syrian kids being trained at amateur sports clubs. This is a sign that they are integrating into the Turkish society' (4 April 2016). NGO Multeci-Der's Ercoban argued that integration policies need to be implemented as '(a)fter a possible 10-15-year stay, there will be a big question mark over whether those people will even want to return' (24 October 2014). 


\section{Conclusion}

The study reveals the discursive strategies utilized by the official news agency of the Turkish government in regard to Syrian refugees. This discourse analysis using the DHA framework helped reveal Turkey's position in the Syrian refugee crisis, communicated by the government as part of its public diplomacy strategy to influence international public opinion. The language used, themes emphasized and discursive strategies utilized by the Turkish government and distributed through its official news agency revealed the significance of discourse analysis to understand the symbiotic relationship between media and public diplomacy efforts, especially when using national news agencies to craft a certain rhetoric about an issue for transmission abroad. The DHA framework was useful in unfolding government discourse in regard to this issue by underlining, especially, the perspectivation of Turkey's support for refugees through external- and self-praise, as well as the argumentation/topoi that support Turkey's reputation: topos of being a good host, and topos of aid to intensify funds spent on refugees. In addition, the valence in the news stories intensifies Turkey's efforts in supporting the refugees while mitigating the efforts and contributions of the international community, especially the EU for not fulfilling its promises, and calling for action such as more help, more sympathy, more funds and more refugees accepted outside Turkey. Results reveal that Anadolu Agency news discourses are embedded with discursive strategies that act as foreign policy relationship management devices, promoting national interests internationally and trying to champion Turkey's involvement with Syria and its contributions to the well-being of Syrian refugees.

Discourse is considered to be a powerful legitimation practice, and media has an invaluable role in disseminating a specific government's response and discourse in an issue. As suggested by Phillips and Hardy (2002), discourse not only reflects social reality but also constructs it. Anadolu Agency reporting, itself increasingly controlled by the Turkish government, plays a crucial public diplomacy role in establishing a favorable international impression for Turkey's efforts in providing for Syrian refugees while simultaneously legitimizing its involvement in the conflict in Syria and leveraging more power in the region. The intensification and mitigation strategies used in the news articles aim to position Turkey as the 'champion of the diplomacy battle' and to secure a place at the table where decisions about Syria's future are being made. In fact, the very recent (October 2019) Operation Peace Spring may be seen as the latest orchestration of exerting more control on these regional goals. In addition, President Erdogan's threats to open Turkey's borders to Europe, thereby using Syrian refugees as a political weapon against the West, plays to the same goal. In early September, Erdogan made the first public threat to 'open the gates' to allow Syrian refugees to migrate to Western countries unless a 'safe zone' is established inside Syria, where Syrian refugees in Turkey could be potentially relocated in the future (Beaumont and Smith, 2019). More recently, after the October 2019 launch of Operation Peace Spring in northern Syria - which has involved airstrikes and artillery fire targeting Kurdish forces that Turkey sees as terrorists Erdogan threatened the opponents of the operation with 'open[ing] the gates and send[ing] 3.6 million refugees your way' (Turak, 2019).

The Anadolu Agency news articles do not reflect such threatening discourse; rather, the news agency is used more like a traditional public diplomacy tool to extract soft power 
with persuasive techniques instead of a threatening tone. The news articles analyzed make use of topoi/argumentation strategies and construct Turkey as a good host, as the country that did and continues to do the most for the Syrian people. Anadolu Agency news articles show Turkey as the savior of the Syrian people, treating refugees fairly from a humanitarian perspective and offering context for their plight by providing human interest stories that show their victimization. The overall goal of such discourse could be to attract more funding from external agencies as well as request more direct action in supporting refugees.

The issue of power is significant in analyzing how Turkey tries to assert its position through helping Syrian refugees in need. The news reports strategically emphasize the external praise of international figures and the self-praise of Turkish authorities to assert Turkey's involvement in the issue and further legitimate its role in the Syrian refugee crisis. Furthermore, Turkey's goal to bring peace and stability back to the region is reiterated in various news reports that work to legitimize Turkey's foreign policy and military operations in Syria. Revealing such power structures and their political implications is important, because discourse produces a certain reality for refugees and CDA: '[ . . ] places language as its topic of investigation rather than seeing it as a simple and passive medium' (Guilfoyle and Hancock, 2009: 127).

Looking at the discourse used historically, an interesting finding was how discourse used by Turkish government has changed after the March 2016 EU-Turkey Deal. Comparing the findings and percentages from news stories published until December 2016 (62\% of the total stories), and after January 2017 until end of 2018 (38\% of the total), revealed that the predication strategy of victimization has decreased by $13 \%$, which indicated that the Syrian refugees are less frequently shown through their victimhood or through human interest stories. More than 8 years into the Syrian crisis, this change might be related to the growing intolerance or backlash in sentiment toward Syrian refugees in Turkey as well as more generalized public fatigue on the issue. In contrast, self- and also external praise about Turkey's contribution to Syrian refugees has increased by $31.5 \%$ and $10 \%$, respectively. This increase in the discursive strategy of praise might be related to Turkey's public diplomacy strategy, through which Turkey communicates its stellar job in providing for refugees, and at the same time revealing how non-Turkish others acknowledge Turkey's efforts in this regard. This reported praise might then be used to help legitimize Turkey's position in regard to Syria, highlighting its urge to gain a place at the table.

Guilfoyle and Hancock (2009) have argued that

the focus of discourse analysis should be less on personal narratives of the refugee communities, more on those of the host society/community, and the aim is to show whether the discourses of the host society (policy, media, and everyday speech) are welcoming/supportive, or whether their discourses exclude those welcoming/supporting structures. (p. 129)

The unique contribution of this study is to reveal the ideology of the host society through an analysis of national news agency constructions and to discuss how the Turkish government has leveraged Syrian refugees as a public diplomacy tool to influence international public opinion and possibly ensure support for Turkey's role in regional politics and involvement in Syria. Themes highlighted in Turkish news reports and the argumentations they put 
forward reveal Turkey's critical perspective of the international community, especially Western countries, for not fulfilling their humanitarian responsibilities. Such rhetorical attacks by the Turkish government through official news agency reporting impose blame on the international community for remaining insensitive to the despair of Syrian refugees. Such discursive strategies in news stories reposition Turkey as an ally of those in need and a good neighbor, while positioning the West as an uncaring antagonist that has failed to fulfill its promises. News reporting then becomes a public diplomacy tool to strengthen Turkey's stance and to advocate for its leadership in regional and international politics. Contributing to media discourse through Anadolu Agency allows the government to further communicate about the refugees as it sees fit, actively constructing the 'winners and losers' of the Syrian refugee crisis, pointing fingers at those whom it deems responsible, and further naming and shaming 'Western powers' for running away from their responsibilities.

Our perception of the world and our presumptions about the issues we face are framed by the information we can access, and in this context mass media discourses are critical. The current study, embedded within the broader sociopolitical and historical context of the Syrian conflict, reveals that the Turkish government has structured its response to the refugee crisis within a normative framework that suggests that helping those in need is its humanitarian responsibility. However, a detailed reading of Turkey's news discourse also invites a critical examination of its mediated public diplomacy efforts. When the conditions of refugees, their experiences and their status in host society are examined in detail through official discursive practices, it becomes apparent that what is omitted, missing or mitigated is as important as what is presented. In fact, most of Anadolu Agency's reporting is based on the responses of national and international state actors and leaders of international organizations, and not the voices of the refugees themselves. Governments thus harness the power of mass media to promote soft power of public diplomacy and try to persuade audiences to accept their account of events, no matter how partial or fragmented this account might be.

This study mainly focused on Turkey's use of discursive strategies in communicating about the refugee crisis and aimed to reveal how the country positioned itself in regard to the Syrian refugee crisis. Future studies could examine the extent to which these national discursive strategies and rhetorical representations have influenced international news coverage. For example, Syrian refugee news stories published in reputable international newspapers such as the New York Times or The Guardian could be analyzed to find out how they do or do not reflect these Turkish public diplomacy efforts in the international media sphere. Alternatively, one could make a comparative analysis of how another country (like the United Kingdom or the United States) uses its own public diplomacy efforts in relation to the Syrian refugee crisis to reflect its own position on the issue. This could be analyzed in detail to reveal how public diplomacy functions in various contexts and to understand the factors that contribute to its overall effectiveness. In addition, one could also study social media discourses by integrating a social media CDA component. This could include an analysis of the comments shared under Turkish and international news stories which relate to Syrian refugees (published in The Guardian, the New York Times, etc.). An examination of this could be used to compare the different attitudes toward Syrian refugees in various countries and to try to understand the reasons behind the differences through DHA. 


\section{Declaration of conflicting interests}

The author(s) declared no potential conflicts of interest with respect to the research, authorship, and/or publication of this article.

\section{Funding}

The author(s) received no financial support for the research, authorship and/or publication of this article.

\section{References}

Anadolu Ajans1 History (2018) History of Anadolu Agency from its foundation to the present. Available at: https://www.aa.com.tr/en/p/history (accessed 2 October 2018).

Anholt S and Hildreth $\mathrm{j}$ (2005) Let freedom and cash registers ring: America as a brand. Place Branding 1(2): 164-172.

Asante MK (2014) Facing South to Africa: Toward an Afrocentric Critical Orientation. Lanham, MD: Lexington Books.

Beaumont P and Smith H (2019) Erdoğan: I'll let Syrian refugees leave Turkey for west unless safe zone set up. The Guardian, 5 September. Available at: https://www.theguardian.com/ world/2019/sep/05/erdogan-ill-let-syrian-refugees-leave-turkey-for-west-unless-safe-zoneset-up (accessed 30 October).

Bigo D (2002) Security and immigration: Toward a critique of the governmentality of unease. Alternatives: Global, Local, Political 27(1): 63-92.

Chavez LR (2001) Covering Immigration: Popular Images and the Politics of a Nation. Berkeley, CA: University of California Press.

Cisneros JD (2008) Contaminated communities: The metaphor of 'immigrant as pollutant' in media representations of immigration. Rhetoric and Public Affairs 11: 569-601.

Dimitrova DV, Ozdora-Aksak E and Connolly-Ahern C (2018) On the border of the Syrian refugee crisis: Views from two different cultural perspectives. American Behavioral Scientist 62(4): 532-546.

Fairclough N (1989) Language and Power. London: Longman.

Fairclough N (1995) Media Discourse. London: Edward Arnold.

Fairclough N and Wodak R (1997) Critical discourse analysis. In: Van Dijk T (ed.) Discourse Studies: A Multidisciplinary Introduction. London: SAGE, pp. 258-284.

Fitzgerald J, Curtis KA and Corliss CL (2012) Anxious publics worries about crime and immigration. Comparative Political Studies 45(4): 477-506.

Gabrielatos C and Baker P (2008) Fleeing, sneaking, flooding: A corpus analysis of discursive constructions of refugees and asylum seekers in the UK press 1996- 2005. Journal of English Linguistics 36(1): 5-38.

Grunig JE (1993) Public relations and international affairs: Effects, ethics and responsibility. Journal of International Affairs 47(1): 137-162.

Guilfoyle A and Hancock P (2009) Discourses and refugees' social inclusion: Introduction to method and issues. Tamara: Journal of Critical Organization Inquiry 8(1-2): 123-132.

Hercowitz-Amir A, Raijman R and Davidov E (2017) Host or hostile? Attitudes towards asylum seekers in Israel and in Denmark. International Journal of Comparative Sociology 58(5): 416-439.

KhosraviNik M (2009) The representation of refugees, asylum seekers and immigrants in British newspapers during the Balkan conflict (1999) and the British general election (2005). Discourse \& Society 20(4): 477-498. 
Klocker N and Dunn KM (2003) Who's driving the asylum debate? Newspaper and government representations of asylum seekers. Media International Australia 109: 71-93.

Kunczik M (1997) Images of Nations and International Public Relations. Mahwah, NJ: Lawrence Erlbaum.

Lihua L (2012) Discourse and Manipulation: Stories about China in the New York Times. Language \& Communication 32(3): 249-256.

Machin D and Van Leeuwen T (2007) Global Media Discourse: A Critical Introduction. New York and London: Routledge.

Mowlana H (2016) The role of media in contemporary international relations: Culture and politics at the crossroads. Journal of Multicultural Discourses 11(1): 84-96.

Phillips N and Hardy C (2002) Discourse Analysis: Investigating Processes of Social Construction. Thousand Oaks, CA: SAGE.

Reisigl M and Wodak R (2009) The discourse-historical (DHA). In: Wodak R and Meyer M (eds) Methods in Critical Discourse Analysis. London: SAGE, pp. 87-121.

Sheafer T and Gabay I (2009) Mediated public diplomacy: A strategic contest over international agenda building and frame building. Political Communication 26(4): 447-467.

Tehranian M (2014) Ethnic discourse and the new world disorder: A communitarian perspective. In: Asante MK, Yoshitaka M and Yin J (eds) The Global Intercultural Communication Reader, 2nd edn. New York: Routledge, pp. 431-444.

Tuch HN (1990) Communicating with the World: U.S. Public Diplomacy Overseas. New York: St. Martin's Press.

Turak N (2019) Turkey's Erdogan threatens to release millions of refugees into Europe over criticism of Syria offensive. CNBC, 10 October. Available at: https://www.cnbc.com/2019/10/10/ turkeys-erdogan-threatens-release-of-refugees-to-europe-over-syria-criticism.html (accessed 30 October).

United Nations High Commissioner for Refugees (UNHCR) (n.d.) Refugees and asylum seekers in Turkey. Available at: https://www.unhcr.org/tr/en/refugees-and-asylum-seekers-in-turkey (accessed 14 June 2019).

Van Dijk TA (2003) Ideology and Discourse: A Multidisciplinary Introduction. Barcelona: Ariel.

Van Dijk TA (2006) Ideology and discourse analysis. Journal of Political Ideologies 11(2): $115-140$.

Van Gorp B (2005) Where is the frame? Victims and intruders in the Belgian press coverage of asylum issue. European Journal of Communication 20(4): 484-507.

Van Leeuwen T (2008) Discourse and Practice: New Tools for Critical Discourse Analysis. Oxford: Oxford University Press.

Van Leeuwen T and Wodak R (1999) Legitimizing immigration control: A discourse-historical analysis. Discourse Studies 1(1): 83-118.

Vanc AM and Fitzpatrick KR (2016) Scope and status of public diplomacy research by public relations scholars 1990-2014. Public Relations Review 42(3): 432-440.

Wang J (2006) Managing national reputation and international relations in the global era: Public diplomacy revisited. Public Relations Review 32(2): 91-96.

Wang J (2007) Telling the American story to the world: The purpose of the U.S. public diplomacy in historical perspective. Public Relations Review 33(1): 21-30.

Wodak R (1996) The genesis of racist discourse in Austria since 1989. In: Coulthard CR and Coulthard M (eds) Texts and Practices. London and New York: Routledge, pp. 107-128.

Wodak R and Meyer M (2009) Critical discourse analysis: History, agenda, theory, and methodology. In: Wodak R and Meyer M (eds) Methods for Critical Discourse Analysis. London: SAGE, pp. 1-34.

Xu S (2014) Chinese Discourse Studies. Basingstoke: Palgrave Macmillan. 
Young R (ed.) (1981) Untying the Text: A Post-Structural Anthology. Boston, MA: Routledge.

Zhang J (2006) Public diplomacy as symbolic interactions: A case study of Asian tsunami relief campaigns. Public Relations Review 32(1): 26-32.

\section{Author biography}

Emel Özdora Akşak is employed as an Assistant Professor at the Department of Communication and Design at Bilkent University. She received her PhD in Mass Communication from the University of Florida in 2009. Her research interests include public relations, organizational communication, public diplomacy and public relations. Her work has been published in the American Behavioral Scientist, Public Relations Review, Business Ethics: A European Review and elsewhere. With a research grant from the Arthur Page Center for Integrity in Public Communication, her current focus is on Syrian refugees living in Turkey. 